\title{
Sindrom Kasabach-Merritt
}

\author{
Ellya Marliah, Djajadiman Gatot
}

\begin{abstract}
Seorang bayi perempuan berumur 4 bulan, dirawat di departemen Ilmu Kesehatan Anak RS Dr. Cipto Mangunkusumo (RSCM) dengan diagnosis sindrom Kasabach-Merrit (SKM). Diagnosis ditegakkan berdasarkan adanya bercak berwarna ungu sejak lahir yang membesar dan melebar dengan cepat. Hasil laboratorium menunjukkan adanya anemia hemolitik dan trombositopenia sebagai akibat gangguan koagulasi konsumtif. Pemeriksaan MRA (magnetic resonance angiography) menunjukkan adanya hemangiom kavernosa besar di seluruh otot tungkai atas kanan dengan tanda infiltrasi ke dalam rongga pelvis. Tidak tampak tanda organomegali dan hidronefrosis. Pada pasien ini tidak dilakukan biopsi karena dikhawatirkan terjadinya perdarahan. Terapi yang diberikan ialah kombinasi triamsinolon dan bleomisin. Kombinasi kedua obat tersebut memberikan respons yang baik, terlihat terjadi pengecilan lesi dan perbaikan parameter hematologis. Tindakan operasi tidak dilakukan karena lesi yang terlalu besar, namun ternyata dengan terapi konservatif dapat mangatasi menifestasi klinis yang timbul.
\end{abstract}

Kata kunci: Sindrom Kasabach-Merritt, hemangiom

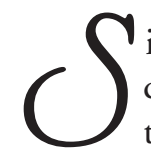
indrom Kasabach-Merritt pertama kali dilaporkan oleh Kasabach dan Merritt pada tahun 1940, ketika menemukan kasus seorang bayi laki-laki dengan hemangiom kapiler pada paha kiri yang membesar dan melebar ke seluruh tungkai kiri, perut, dan dada disertai purpura yang luas yang disebabkan oleh trombositopenia dan koagulopati. ${ }^{1,2}$

Sindrom Kasabach-Merritt merupakan suatu kelainan yang ditandai adanya hemangioma raksasa yang melebar dengan cepat, disertai trombositopenia dan kadang-kadang disertai koagulopati konsumtif. ${ }^{3-6}$ Penyakit ini muncul tersering pada minggu pertama kehidupan yang menyerang anggota gerak atau badan. ${ }^{7}$ Kelainan vaskular ini ternyata berbeda dengan hemangiom klasik. Gambaran histopatologis SKM

\footnotetext{
Alamat korespondensi :

Dr Dajajadiman Gatot, Sp.A(K)

Divisi Hematologi. Departemen Ilmu Kesehatan Anak FKUI-RSCM. Jl. Salemba no. 6, Jakarta 10430. Telepon: 021-3907744, 31901170 Fax.021-3913982.

Dr. Ellya Marliah. PPDS Ilmu Kesehatan Anak FKUI Jakarta
}

mirip dengan tufted angioma atau hemangioendotelioma kaposiform. ${ }^{8,9,10}$ Kasus ini merupakan kasus yang jarang. ${ }^{3}$ Di dalam kepustakaan hanya 200 kasus telah dilaporkan sejak pertama kali dipublikasikan. ${ }^{5}$ Dari data rekam medis Departemen Ilmu Kesehatan Anak FKUI-RSCM, sejak tahun 2000 dilaporkan hanya ada 2 kasus SKM baru.

Makalah ini membahas diagnosis dan tata laksana pasien dengan SKM.

\section{Kasus}

Seorang bayi perempuan, berusia 4 bulan, dirujuk ke RSCM pada tanggal 26 Maret 2004 dengan diagnosis sindrom Kasabach-Merritt. Dari aloanamnesis diketahui bahwa sejak lahir pada paha kanan pasien terlihat bercak berwarna merah-ungu, yang menimbul, berdiameter $3 \mathrm{~cm}$, tidak mudah berdarah, dan makin lama makin lebar. Pada usia 2 bulan bercak sudah melebar sampai seluruh paha. Saat itu terapi yang diberikan berupa penyinaran sebanyak 3 kali dengan dosis $50 \mathrm{rad}$. Lesi tidak mengecil setelah dilakukan 
penyinaran, bahkan semakin membesar dan melebar ke arah betis dan ke arah bokong kanan. Pasien dibawa berobat ke dokter spesialis bedah plastik dan pemeriksaan laboratorium menunjukkan kadar hemoglobin $8,5 \mathrm{~g} / \mathrm{dL}$, hematokrit $27 \mathrm{vol} \%$, jumlah leukosit $7.000 / \mu \mathrm{L}$, jumlah trombosit $140.000 / \mu \mathrm{L}$, eritrosit 3,4 juta/ $\mu \mathrm{L}$, dengan hitung jenis basofil $0 \%$, eosinofil $2 \%$, batang $1 \%$, segmen $36 \%$, limfosit $53 \%$, monosit $8 \%$, masa protrombin 11,5 detik (kontrol 12,2 detik), masa perdarahan 3 menit, masa pembekuan 12 menit. Pasien mendapat transfusi packed red cell (PRC), triamsinolon asetanoid $3 \times 3 \mathrm{mg}$ intralesi, asam salisilat $2 \times 20 \mathrm{mg}$ per oral, bleomisin 1 x $3 \mathrm{mg}$ intravena (2 kali seminggu), sulfas ferosus dan vitamin C. Setelah 12 hari perawatan, pasien dirujuk ke RSCM untuk pemeriksaan dan tata laksana selanjutnya.

Pada pemeriksaan fisis ditemukan bayi sadar, aktif, tidak sesak, tidak sianosis, dan tidak tampak pucat. Berat badan $6,8 \mathrm{~kg}$, panjang badan $64 \mathrm{~cm}$. Laju nadi=laju denyut jantung $124 \mathrm{x} /$ menit, teratur, isi cukup, laju pernapasan $28 \mathrm{x} /$ menit, teratur, kedalaman cukup, suhu aksila $36,8^{\circ} \mathrm{C}$. Pada kepala tidak tampak deformitas. Konjungtiva tidak pucat, sklera tidak ikterik. Pada telinga, hidung, dan tenggorok tidak didapatkan kelainan. Jantung dan paru normal; perut membuncit, lemas bising usus normal. Hati teraba lobus kanan 5 $\mathrm{cm}$ di bawah arcus costae, lobus kiri $4 \mathrm{~cm}$ di bawah prosesus xifoideus, konsistensi kenyal, tepi tajam, permukaan rata; limpa teraba Schuffner 2. Alat gerak pada perabaan teraba hangat, perfusi perifer baik. Lingkar terbesar paha kiri $18 \mathrm{~cm}$. Pada status lokalis di daerah tungkai atas kanan tampak benjolan yang

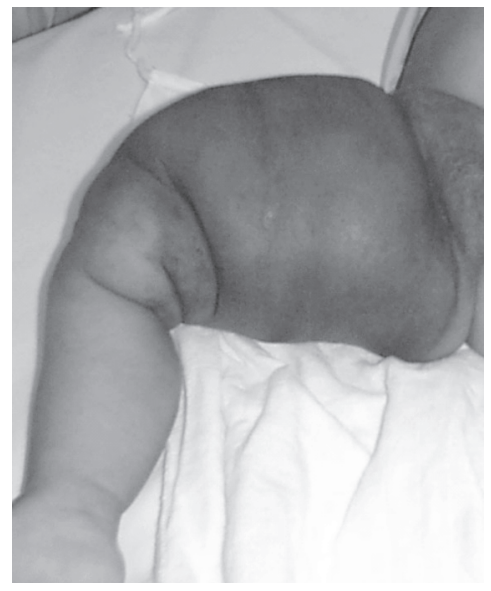

Gambar 1. Lesi pada tungkai atas kanan mengikuti bentuk paha, rata, merah kebiruan di paha kanan, meluas sampai labia mayora kanan, berbatas tegas, tidak nyeri tekan, teraba lebih keras dan lebih hangat, dengan lingkar terbesar $38 \mathrm{~cm}$ (Gambar 1).

Dari pemeriksaan darah tepi saat masuk didapatkan kadar hemoglobin $11 \mathrm{~g} / \mathrm{dL}$, hematokrit 35 vol\%, jumlah leukosit $6.400 / \mu \mathrm{L}$, trombosit $25.000 / \mu \mathrm{L}$, dengan hitung jenis basofil $0 \%$, eosinofil $0 \%$, batang $0 \%$, segmen $58 \%$, limfosit $37 \%$, monosit $5 \%$. Sediaan hapus darah tepi menunjukkan gambaran eritrosit mikrostik, hipokrom, poikilositosis dan fragmentosit. Terapi bleomisin $1 \times 3 \mathrm{mg}$ intravena (2 kali seminggu), triamsinolon asetanoid $3 \times 3 \mathrm{mg}$ per oral, asam salisilat dihentikan.

Hasil pemeriksaan magnetic resonance angiography (MRA) pada tanggal 3 April 2004 menunjukkan adanya hemangiom kavernosa besar di dalam seluruh otot tungkai atas kanan, tampak tanda-tanda infiltrasi lesi ke dalam rongga pelvis melalui celah di antara bulibuli dan tulang ilium kanan sampai di midpelvis. Tidak tampak malformasi arteri vena, tidak tampak hemangiom di rongga abdomen atas. Organ-organ lain di dalam abdomen bagian atas dalam batas normal. Tidak tampak lesi osteolitik pada tulang femur, pelvis, dan tulang belakang lumbosakral. Tidak tampak tandatanda viseromegali dan hidronefrosis yang mengarah pada Kasabach-Merritt (Gambar 2).

Dari hasil konsultasi dengan Departemen Bedah Vaskular disarankan untuk mencegah trauma, dilakukan kompresi dengan verban elastik dan terapi konservatif sampai umur optimal untuk dilakukan operasi. Pasien pulang pada hari ke-15 perawatan dan melanjutkan terapi sitostatik bleomisin $1 \times 3 \mathrm{mg}$

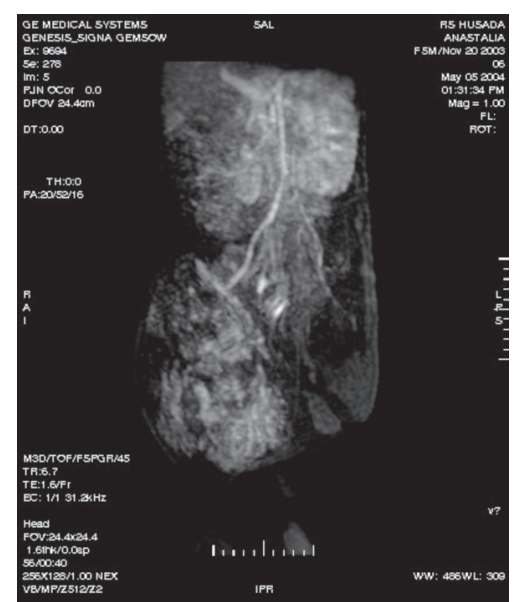

Gambar 2. Hasil pemeriksaan magnetic resonance angiography (MRA) 
intravena ( 2 kali seminggu), triamsinolon asetanoid 3 x $3 \mathrm{mg}$ per oral.

Selama pemantauan, tampak lesi mengecil dengan lingkar paha kanan terbesar $36 \mathrm{~cm}$, tidak tampak perluasan lesi ke sekitarnya dan pemeriksaan darah terakhir didapatkan hasil kadar hemoglobin $11 \mathrm{~g} / \mathrm{dL}$, hematokrit $34 \mathrm{vol} \%$, jumlah leukosit $7.200 / \mu \mathrm{L}$, dan trombosit $103.000 / \mu \mathrm{L}$.

\section{Diskusi}

Sindrom Kasabach-Merritt (SKM) adalah suatu penyakit yang terdiri atas hemangioma raksasa yang melebar dengan cepat disertai trombositopenia, koagulopati konsumtif, pemanjangan masa protrombin, dan masa tromboplastin parsial serta hipofibrinogenemia dengan atau tanpa anemia hemolitik mikroangiopati. ${ }^{3,4,5}$ Kelainan ini dapat ditemukan sejak lahir atau beberapa hari setelah lahir. ${ }^{7}$ Lebih dari $80 \%$ SKM timbul pada usia kurang dari satu tahun dan pada kasus ini berumur 4 bulan. Di dalam kepustakaan hanya 200 kasus telah dilaporkan sejak pertama kali ditemukan. ${ }^{5}$ Kelainan ini tidak dipengaruhi ras maupun etnik, dapat mengenai lakilaki maupun perempuan. ${ }^{8,10}$ Diperkirakan terdapat kurang dari 1\% kasus SKM dari semua kasus hemangiom. ${ }^{2}$ Sindrom Kasabach-Merritt sering dikatakan merupakan komplikasi dari hemangioma, tetapi kelainan vaskular yang mendasarinya bukan hemangiom klasik. ${ }^{9}$ Istilah hemangioma untuk SKM kurang tepat untuk menjelaskan tentang kelainan vaskular pada anak termasuk tumor dan malformasi pembuluh darah. Mulliken dan Glowachi pada tahun 1982 sebagaimana dikutip oleh Drolet mengemukakan penggunaan istilah hemangioma dipakai untuk menerangkan adanya kelainan vaskular dengan pertumbuhan yang cepat, disertai proliferasi endotelial dan regresi spontan. ${ }^{11}$ Dalam klasifikasi terbaru SKM adalah tumor pembuluh darah pada bayi termasuk hemangioperisitoma, granuloma piogenik, tufted angioma, dan hemangioendotelioma kaposiform. ${ }^{11}$ Tufted angioma dan hemangioendotelioma kaposiform merupakan kelainan vaskular yang sering ditemukan pada SKM. ${ }^{8,9,10}$ Keduanya mengandung sekumpulan kapiler yang berdilatasi dan dibatasi oleh sel endotel yang tipis dengan inti yang gelap dan kecil dan terisi oleh sel-sel darah merah. ${ }^{10}$
Patogenesis belum diketahui pasti, diduga akibat terperangkapnya trombosit dalam proliferasi endotel abnormal. Hal ini mengakibatkan aktivasi trombosit dan faktor-faktor pembekuan sehingga terjadi trombosis intralesi. Aliran darah yang berlebihan akibat adanya pirau arteri-vena akan meningkatkan aktivasi trombosit, terjadi konsumsi trombosit, dan faktor pembekuan bersamaan dengan permulaan fibrinolisis, disertai perdarahan intralesi dan pembesaran hemangiom yang mendadak. ${ }^{1,2,12}$ Konsumsi trombosit dan faktor pembekuan dapat melanjut menjadi koagulasi intravaskular diseminata (KID) dan anemia hemolitik mikroangiopati. Anemia dapat terjadi walaupun jarang, terutama pada hemangiom yang besar. Pada umumnya penurunan kadar fibrinogen plasma dan trombosit yang cepat dengan peningkatan fibrin degradation product (FDP) atau D-dimer merupakan petanda dimulainya atau berulangnya koagulopati. ${ }^{2}$ Mekanisme yang menyebabkan pertumbuhan dan involusi lesi vaskular SKM belum jelas. Basic fibroblast growth factor (bFGF) yang meningkat ditemukan dalam urin pasien dengan angiogenesis aktif dan kadarnya akan menurun jika respons terhadap terapi baik. ${ }^{1}$

Lesi vaskular khas berwarna kemerahan atau keunguan yang berbatas tegas, mengkilat, agak kehitaman, dan meluas cepat dalam 12-18 bulan pertama. ${ }^{10}$ Sebagian besar lesi SKM terdapat pada anggota gerak, tetapi tidak ada predileksi tempat tertentu. ${ }^{9,10,12}$ Lesi vaskular SKM selain terdapat pada kulit, dapat juga ditemukan pada organ visera, terutama rongga retroperitoneal yang dapat menyebabkan gejala klinis berat. Jika lesi terdapat di organ visera dapat ditemukan perut membesar, dapat juga terjadi ikterik atau hepatomegali jika lesi terdapat di hati. ${ }^{13}$ Lokasi dan ukuran lesi tidak berhubungan dengan derajat gangguan hematologi yang timbul. ${ }^{1}$ Trombositopenia dan koagulopati pada awalnya tidak menonjol, tetapi dengan bertambah besar lesi dan bertambah usia anak, gejala akan bertambah berat. ${ }^{13}$ Pada kasus yang berat dapat menimbulkan perdarahan spontan berupa petekie, ekimosis, serta dapat terjadi perdarahan yang menyeluruh. ${ }^{10,14}$ Anemia dapat terjadi pada lesi yang besar sehingga anak terlihat pucat. ${ }^{13}$ Kadang-kadang lesi terasa nyeri, dapat terjadi ulserasi dan infeksi. ${ }^{10,13,15}$ Besarnya volume darah yang beredar di lesi dan adanya fistula arteri-vena dapat menyebabkan gagal jantung. ${ }^{13,16}$ 
Pemeriksaan hematologis pada SKM meliputi pemeriksaan hemoglobin, hematokrit, hitung trombosit, dan sediaan darah hapus untuk menemukan fragmen sel darah merah bila terjadi anemia hemolitik. Pada kasus ini sudah terjadi trombositopenia dan anemia. Pemeriksaan masa protrombin dan masa tromboplastin parsial serta kadar fibrinogen akan menunjukkan hasil yang memanjang berhubungan dengan koagulasi intravaskular diseminata. ${ }^{2,13}$ Pemeriksaan pencitraan menunjukkan gambaran masa jaringan lunak difus dan adanya peningkatan aliran darah di dalam dan di sekitar masa. Pemeriksaan CT-scan dan magnetic resonance imaging (MRI) dapat mendeteksi adanya hemangiom viseralis. ${ }^{13}$ Angiografi merupakan pemeriksaan yang invasif tetapi sangat bermanfaat dalam menentukan ukuran, patensi dan jumlah pembuluh darah asal dan kolateral, terutama dilakukan sebelum embolisasi. Jika angiografi dikombinasi dengan MRI disebut sebagai magnetic resonance angiography (MRA). Pemeriksaan ini akan memberikan informasi yang lebih akurat untuk kasus yang sulit. ${ }^{1}$ Biopsi jarang dilakukan karena adanya risiko perdarahan. ${ }^{9,10}$ Demikian pula pada kasus ini tidak dilakukan biopsi karena ditakutkan terjadi perdarahan.

Pemilihan jenis terapi dilakukan secara empirik dan tidak ada terapi tunggal yang terbukti efektif secara universal. Tujuan terapi untuk mengontrol koagulopati konsumtif dan hemolisis dan mempercepat regresi hemangiom. ${ }^{2,6}$ Terdapat dua pendekatan terapi, yaitu terapi suportif dengan transfusi untuk mengkoreksi dan mempertahankan homeostasis dan terapi kuratif untuk menghentikan proliferasi. Diagnosis dan terapi segera akan memberikan hasil yang optimal. ${ }^{2}$

Steroid digunakan sebagai terapi medikamentosa lini pertama pada SKM karena harganya yang murah dan cara pemberiannya mudah seperti yang dilakukan pada pasien ini. ${ }^{3,6}$ Mekanisme kerja steroid belum jelas, tetapi pada pemberian prednison tampak adanya peningkatan vasokonstriksi, penghambatan fibrinolisis, dan angiogenesis serta peningkatan umur trombosit. ${ }^{6}$ Dosis awal prednison yang dianjurkan $2-4 \mathrm{mg} / \mathrm{kg}$ berat badan per hari. ${ }^{10}$ Dosis dapat dinaikkan sampai $5 \mathrm{mg} / \mathrm{kg}$ berat badan per hari. ${ }^{1,2}$ Pasien akan memberikan respons yang baik terhadap pemberian steroid dalam satu atau dua minggu pertama. Jika tidak ada respons maka dosis harus dinaikkan atau ditambah dengan terapi lain. ${ }^{1}$ Pada kasus dengan lesi di kulit kecil dan terlokalisir, dapat diberikan triamsinolon intralesi dengan dosis $3-5 \mathrm{mg} / \mathrm{kgBB}$ per kali. ${ }^{10}$ Interferon-alfa digunakan sebagai terapi lini kedua jika tidak responsif terhadap steroid, ${ }^{2,3}$ delapan puluh persen kasus memberikan respon yang baik. ${ }^{15}$ Interferonalfa dapat dipakai sebagai terapi lini pertama namun harganya lebih mahal daripada steroid, ${ }^{3,6}$ terapi ini digunakan sejak tahun 1992 sebagai antiproliferatif dan antiangiogenik dengan dosis 3 juta $\mathrm{IU} / \mathrm{m}^{2}$ perhari. ${ }^{3}$ Interferon- $\alpha_{2 \mathrm{a}}$ atau interferon- $\mathrm{a}_{2 \mathrm{~b}}$ dapat dipakai dengan efektifitas yang sama. ${ }^{5}$ Pada penelitian terbaru ditemukan $2-20 \%$ pasien dengan terapi interferon mengalami diplegia tipe spastik, sehingga dianjurkan diberikan hanya pada kasus yang mengancam jiwa dan dalam waktu yang pendek dengan memonitor status neurologis. ${ }^{1,3}$ Sebagian besar pasien dengan gejala neurologis akan berkurang setelah pengobatan dihentikan. ${ }^{5}$ Alternatif terapi lain meliputi kombinasi kemoterapi (vinkristin, siklofosfamid, aktinomisin), antikoagulan (heparin), antitrombin (tiklopidin, pentoksifilin), antifibrinolisin (asam epsilon aminokaproat, asam traneksamid). 2,6 Injeksi bleomisin intralesi dilaporkan cukup efektif. ${ }^{11}$

Kompresi pada lesi terutama lesi pada anggota gerak digunakan sebagai terapi ajuvan. Tindakan ini dapat membantu pada beberapa pasien. Untuk kompresi dapat digunakan kaus kaki khusus, balut elastis atau kompresi intermiten dengan manset. ${ }^{1,17}$ Terapi radiasi dilakukan pada kasus yang berat, tetapi sudah jarang dipakai karena adanya efek samping jangka panjang yaitu terjadinya keganasan (angiosarkoma) dan penurunan pertumbuhan tulang. ${ }^{2,5,6,9}$

Pada lesi kulit tunggal dan tidak terletak di tempat yang vital serta lesi multipel di limpa dan hati dapat dilakukan terapi bedah, yaitu dengan eksisi lokal, amputasi ekstremitas, splenektomi dan pengangkatan hati. ${ }^{1}$ Jika dilakukan eksisi lengkap pada usia satu minggu pertama, sebelum lesi membesar, akan mengurangi morbiditas dan penggunaan terapi farmakologi dengan hasil yang memuaskan. ${ }^{1,6,7}$ Eksisi lokal sulit dilakukan untuk lesi yang luas. ${ }^{13}$ Embolisasi dapat dipertimbangkan pada lesi dengan pembuluh asal tunggal, tetapi berisiko terjadinya penyumbatan pada lokasi yang jauh seperti pada paru. ${ }^{2}$

Lesi SKM memerlukan waktu beberapa bulan untuk dapat mengecil, setelah jumlah trombosit kembali normal dan gangguan pembekuan teratasi. Lesi residual berhubungan dengan efektifitas terapi inisial, terutama kecepatan respon terhadap terapi. ${ }^{8}$ Penyakit ini dapat berakibat fatal apabila mengenai organ vital. Kematian bisa juga terjadi sebagai akibat gagalnya pengobatan yang menyebabkan terjadinya perdarahan masif pada lesi atau tempat lain, ${ }^{2,6,16}$ atau sebagai akibat komplikasi iatrogenik. ${ }^{9}$ 


\section{Daftar Pustaka}

1. Hall GW. Kasabach-Merritt syndrome: pathogenesis and management. Br J Haematol 2001; 112:851-62.

2. Hall GW, Maggs PHBB, Hann IM. Kasabach-Merritt syndrome: caveats of diagnosis and management. Current Paediatr 2000; 10:72-8.

3. Wananukul S, Nuchprayoon I, Seksarn P. Treatment of Kasabach-Merritt syndrome: a stepwise regimen of prednisolon, dypiridamol, and interferon. Int J Dermatol 2003; 42:741-8.

4. Darmstadt GL, Sidbury R. The skin. Dalam: Behrman RE, Vaughn VC, penyunting. Nelson textbook of pediatrics. Edisi ke-17. Philadelphia: WB Saunders Co;2004. h. 2167-72.

5. Hesselmann S, Micke O, Marquardt T, Baas S, Bramswig JH, Marms E, dkk. Kasabach-Merritt syndrome: a review of the therapeutic option and a case report of successful treatment with radiotherapy and interferon alpha. Br J Radiol 2002; 75:180-4.

6. Shin HY, Ryu KH, Ahn HS. Strepwise multimodal approach in the treatment of Kasabach-Merritt syndrome. Pediatr Int 2000; 42:620-4.

7. Drolet BA, Scott LA, Esterly NB, Gosain AK. Early surgical intervention in a patient with Kasabach-Merritt phenomenon. J Pediatr 2001; 138:756-8.

8. Enjolras O, Mulliken JB, Wassef M, Frieden IJ, Rieu PN, Burrows PE, dkk. Residual lesions after KasabachMerritt phenomenon in 41 patients. J Am Acad Dermatol 2000; 42:225-35.

9. Enjolras O, Wassef M, Mazoyer E, Frieden IJ, Rieu PN, Drouet L, dkk. Infants with Kasabach-Merritt syn- drome do not have "true" hemangiomas. J Pediatr 1997; 130:631-40.

10. Krafchik BR. Kasabach-Merritt syndrome. Didapat dari http://www.emedicine.com/med/topic 1221.htm. Diakses tanggal 25 Mei 2004.

11. Drolet BA, Esterly NB, Frieden IJ. Hemangiomas in children. N Engl J Med 1999; 341:173-81. Dalam: Mulliken JB, GlowackiJ. Hemangiomas and vascular malformations in infants and childrens: a classsification based on endothelial characteristics. Plast Reconstr Surg 1982; 69:412-20.

12. Hernandez JA, Morelli JG. Birthmarks of potential medical significance. NeoReviews 2003; 4:263-9.

13. Cheerva AC. Kasabach-Merritt syndrome. Didapat dari http://www. emedicine.com/ped/topic1234. htm. Diakses tanggal 25 Mei 2004.

14. Antaya RJ. Infantile hemangioma. Didapat dari http:// www.emedicine .com/derm/topic201.htm. Diakses tanggal 25 Mei 2004

15. Wysocki M, Maslowska E, Drapinska I, Kurylak D, Boron AB. Life-saving therapy with $a-2 b$ interferon in an infant with Kasabach-Merritt syndrome. Mon Sci Monit 1997; 3:584-8.

16. Deb G, Jenkner A, De Sio L, Boldrini R, Bosman C, Standoli N, dkk. Spindle cell (Kaposiform) hemangioendothelioma with Kasabach-Merritt syndrome in an infant: successful treatment with a-2a interferon. Med Ped Oncol 1997; 28:358-61.

17. Aylett SE, Williams AF, Bevan DH, Holmes SJK. The Kasabach-Merritt syndrome: treatment with intermittent pneumatic compression. Arch Dis Child 1990; 65:790-1. 